\title{
Lack of an effect of CYP3A4 and MDR1 gene polymorphisms on colchicine pharmacogenetics in the treatment of Familial Mediterranean fever
}

\author{
D. Dogruer ${ }^{1}$, E. Tug' 2 C. Bes ${ }^{3}$ and M. Soy ${ }^{3}$ \\ ${ }^{1}$ Department of Medical Genetics, Faculty of Medicine, \\ Abant Izzet Baysal University, Bolu, Turkey \\ ${ }^{2}$ Department of Medical Genetics, Faculty of Medicine, \\ Gazi University, Ankara, Turkey \\ ${ }^{3}$ Department of Rheumatology, Faculty of Medicine, \\ Abant Izzet Baysal University, Bolu, Turkey \\ Corresponding author: E. Tug \\ E-mail: esratug@hotmail.com
}

Genet. Mol. Res. 12 (3): 3521-3528 (2013)

Received July 16, 2012

Accepted September 28, 2012

Published January 24, 2013

DOI http://dx.doi.org/10.4238/2013.January.24.2

\begin{abstract}
The P-gp/MDR1 multidrug transporter mediates detoxification of numerous drugs, including colchicine, and CYP3A4 is key to the biotransformation of colchicine. We investigated the effects of CYP3A4 and P-gp/MDR1 polymorphisms on bioavailability of colchicine in patients with Familial Mediterranean fever (FMF). Forty-eight Turkish patients with FMF treated with colchicine were genotyped for $3435 \mathrm{C}>\mathrm{T},(-) 1 \mathrm{~A}>\mathrm{G}, 61 \mathrm{~A}>\mathrm{G}, 1199 \mathrm{G}>\mathrm{A}, 1236 \mathrm{C}>\mathrm{T}$, $2677 \mathrm{G}>\mathrm{A}, 2677 \mathrm{G}>\mathrm{T}$ polymorphisms in the $\mathrm{P}-\mathrm{gp} / \mathrm{MDR} 1$ gene and $3435 \mathrm{C}>\mathrm{T}, \quad * 1 \mathrm{~B}(-392 \mathrm{~A}>\mathrm{G}), \quad * 2(15713 \mathrm{~T}>\mathrm{C}), \quad * 3(23171 \mathrm{~T}>\mathrm{C})$, $* 12(21896 \mathrm{C}>\mathrm{T}), * 17(15615 \mathrm{~T}>\mathrm{C})$ polymorphisms in the CYP3A4 gene. Doses of colchicine administered to patients did not differ with respect to $P-g p / M D R 1$ or $C Y P 3 A 4$ gene polymorphism. We also
\end{abstract}


determined the genotype distributions of CYP $3 A 4$ and $P$-gp/MDR1 genes among FMF patients. There was no significant gender difference in the $P-g p / M D R 1$ polymorphism, whereas there were significant gender differences in the frequencies of $15713 \mathrm{~T}>\mathrm{C}$ and $15615 \mathrm{~T}>\mathrm{C}$ polymorphisms in the CYP $3 A 4$ gene. No significant relationship was found between colchicine doses that would introduce optimal clinical response and affect the therapeutic dose and CYP3A4 and $P$-gp/MDR 1 gene polymorphisms in these FMF patients.

Key words: Colchicine; $P$-gp/MDR1; CYP3A4; Pharmacogenetics; Familial Mediterranean fever

\section{INTRODUCTION}

Colchicine is used to treat Familial Mediterranean fever (FMF) but is valuable in other inflammatory diseases such as gouty arthritis, Behçet's disease, and recurring pericarditis with effusion (Niel and Shermann, 2006; Cocco et al., 2010). Three proteins mediate colchicine pharmacokinetics: tubulin, cytochrome P450 3A4 (CYP3A4), and P-glycoprotein (P-gp). Tubulin is a colchicine receptor that governs the plasma elimination half-life of the drug. Intestinal and hepatic CYP3A4 is fundamental in the biotransformation of colchicine. P-gp is a cell efflux pump that regulates the tissue distribution of colchicine and its excretion via the biliary tract and kidneys (Niel and Shermann, 2006). P-gp, encoded by the multidrug resistance 1 gene $(P$-gp/MDR1, also known as $A B C B 1)$, is expressed in several organs, including the intestine, liver, and kidney, and mediates detoxification of numerous drugs such as colchicine (Ambudkar et al., 1999; Kimura et al., 2007). P-gp affects the absorption, distribution, and elimination of its substrates. The $P$-gp/MDR1 gene is highly polymorphic, with approximately 50 single nucleotide polymorphisms (SNPs) in the coding exons (Vicente et al., 2008). These variants alter the pharmacokinetics and pharmacodynamics of several P-gp drug substrates, accounting for differences in bioavailability in some substrate classes (Hoffmeyer et al., 2000; Kim et al., 2001; Jamroziak et al., 2004; Vicente et al., 2008). Altered $P$-gp/MDRl activity due to induction and/or inhibition can cause drugdrug interactions with altered drug pharmacokinetics and response (Zhou, 2008). When inhibitors or modulators are prescribed in combination, changes in P-gp activity may lead to intracellular accumulation of colchicine and increased pharmacological or toxic effects. These sites are also key colchicine targets that may explain the wide inter-individual variations in responses to the drug (Niel and Shermann, 2006).

The main route of colchicine elimination is via hepatobiliary excretion (Ferron et al., 1996; Tateishi et al., 1997; Dvorak et al., 2003) and with the feces (Tateishi et al., 1997; Dvorak et al., 2003). Kidneys contribute to $<20 \%$ of clearance (Lange et al., 2001; Molad, 2002; Niel and Shermann, 2006). The steroid hydroxylase CYP3A4 is the most abundant P-450 enzyme in the human liver, metabolizing more than $50 \%$ of prescription drugs. Cytochrome $P-450$ genes constitute a superfamily encoding different isoenzymes that account for phase I drug metabolism. In humans, more than 40 cytochrome P-450s have been identified and sequenced (Hasler, 1999; Nebert and Russell, 2002). CYP3A4 is abundantly and constitutively expressed in hepatic and intestinal epithelia (Hesselink et al., 2003), so the reported increase 
in transcriptional activity shown by the $C Y P 3 A 4 * 1 B$ allele in vitro would theoretically also reflect significant enzymatic activity in vivo (Turolo et al., 2010).

In this study, we explored the relationship between CYP3A4 and P-gp/MDR1 polymorphisms and therapeutic colchicine dose in FMF patients.

\section{MATERIAL AND METHODS}

\section{Patient selection}

The Human Research Ethics Committee of Abant Izzet Baysal University approved the study (\#2009/100-39). All patients who were invited to join the study agreed to participate. All patients gave informed consent for molecular testing. A total of 48 patients aged 16 years and over (mean age $33.24 \pm 12.32$ ) and diagnosed with FMF according to Tel-Hashomer criteria (Fonnesu et al., 2009) were enrolled. Although the female-to-male ratio was 1.28 (27/21), there was a significant difference between females and males $(\mathrm{P}=0.02)$. Mean age at onset of symptoms was $16.5 \pm 11$ (14.5 \pm 9.34 in females and $19 \pm 13.7$ in males). Demographic features are presented in Table 1.

The disease severity score of each patient was calculated according to the scoring system suggested by Pras et al. (1998). None of the patients was using CYP3A4 and P-gp/MDR1 substrate or CYP3A4 and $P-g p / M D R 1$ inhibiting drugs other than colchicine.

\section{DNA extraction and $M E F V$ gene analysis}

Peripheral venous blood samples $(3 \mathrm{~mL})$ were collected in EDTA tubes. Genomic DNA was extracted with Blood DNA Extraction Kits (Vivantis, Malesia). The most common 5 (M694V, M680I, M694I, V726A, E148Q) mutations in exons 2 and 10 of the $M E F V$ (Mediterranean fever) gene were determined by real-time PCR on a Rotor Gene 6000 LightCycler (Corbett Life Science, Concord, NSW, Australia) according to manufacturer protocols (Dr. Zeydanli, Turkey).

\section{P-gp/MDR1 and CYP3A4 polymorphisms}

In our study group, the T-129C polymorphism of the $P$-gp/MDRl gene was non-informative. $3435 \mathrm{C}>\mathrm{T},(-) 1 \mathrm{~A}>\mathrm{G}, 61 \mathrm{~A}>\mathrm{G}, 1199 \mathrm{G}>\mathrm{A}, 1236 \mathrm{C}>\mathrm{T}, 2677 \mathrm{G}>\mathrm{A}$, and $2677 \mathrm{G}>\mathrm{T}$ in $P-g p /$ MDR1 and 3435C $>\mathrm{T}, * 1 \mathrm{~B}(-392 \mathrm{~A}>\mathrm{G}), * 2(15713 \mathrm{~T}>\mathrm{C}), * 3(23171 \mathrm{~T}>\mathrm{C}), * 12(21896 \mathrm{C}>\mathrm{T})$, and $* 17(15615 \mathrm{~T}>\mathrm{C})$ in $C Y P 3 A 4$ were analyzed as described by the manufacturer on a fullyautomated microarray-based analyzer (INFINITI ${ }^{\mathrm{TM}}$, AutoGenomics, Inc., Vista, CA, USA).

\section{Statistical analyses}

SPSS (Statistical Package for Social Sciences) for Windows v16.0 was used for data analysis. Continuous variables are reported as means \pm standard deviation. Continuous and categorical variables were compared by the Student $t$-test and chi-square tests, respectively. Comparisons of parametric variables were carried out by ANOVA with Tukey's post hoc testing while those of non-parametric variables and percentages were performed by KruskalWallis and chi-square tests. $\mathrm{P}<0.05$ was considered to be significant in all tests. 


\section{RESULTS}

Among the clinical findings of the disease, presence of erythema differed significantly between males and females $(\mathrm{P}=0.02)$, while none of the other symptoms statistically differed between genders $(\mathrm{P}>0.05)$ (Table 1). Table 2 shows the distribution of MEFV gene mutations with respect to gender and colchicine dose.

Table 1. Frequency of clinical features of the disease in females and males.

\begin{tabular}{llrl}
\hline & Female $(\%)$ & Male $(\%)$ & P \\
\hline Mean age & $30.95 \pm 12.6(\mathrm{~N}=27)$ & $36.21 \pm 11.5(\mathrm{~N}=21)$ & $0.02 *$ \\
Fever & $85.1(\mathrm{~N}=24)$ & $85.7(\mathrm{~N}=18)$ & 0.88 \\
Peritonitis & $96.2(\mathrm{~N}=26)$ & $100.0(\mathrm{~N}=21)$ & 0.21 \\
Pleuritis & $11.1(\mathrm{~N}=3)$ & $14.2(\mathrm{~N}=3)$ & 0.26 \\
Arthritis & $44.4(\mathrm{~N}=12)$ & $38.0(\mathrm{~N}=8)$ & 0.66 \\
Erythema & $22.2(\mathrm{~N}=6)$ & $4.7(\mathrm{~N}=1)$ & $0.02 *$ \\
Amyloidosis & $-(\mathrm{N}=0)$ & $4.7(\mathrm{~N}=1)$ & 0.25 \\
Proteinuria & $7.4(\mathrm{~N}=2)$ & $9.5(\mathrm{~N}=2)$ & 0.09 \\
Splenomegaly & $11.1(\mathrm{~N}=3)$ & $4.7(\mathrm{~N}=1)$ & 0.27 \\
History of appendectomy & $33.3(\mathrm{~N}=9)$ & $28.5(\mathrm{~N}=6)$ & 0.82 \\
\hline
\end{tabular}

*Statistically significant.

Table 2. Distribution of MEFV gene mutations with regard to gender and colchicine dose.

\begin{tabular}{|c|c|c|c|c|c|c|c|c|}
\hline \multirow{2}{*}{$\begin{array}{l}M E F V \text { gene } \\
\text { mutations }\end{array}$} & \multicolumn{2}{|c|}{ Patients (\%) } & \multirow[t]{2}{*}{$\mathrm{P}$} & \multirow[t]{2}{*}{ Genotype } & \multicolumn{3}{|c|}{ Colchicine dose $(\%)$} & \multirow[t]{2}{*}{$\mathrm{P}$} \\
\hline & Female & Male & & & $1 \times 1 *$ & $2 \times 1 *$ & $3 \times 1 *$ & \\
\hline M694V & $59.3(\mathrm{~N}=16)$ & $66.7(\mathrm{~N}=14)$ & 0.449 & $\begin{array}{l}\text { Heterozygote }(\mathrm{N}=30) \\
\text { Homozygote }(\mathrm{N}=18)\end{array}$ & $\begin{array}{r}6.6(\mathrm{~N}=2) \\
-(\mathrm{N}=0)\end{array}$ & $\begin{array}{l}56.7(\mathrm{~N}=17) \\
33.3(\mathrm{~N}=6)\end{array}$ & $\begin{array}{l}36.7(\mathrm{~N}=11) \\
66.6(\mathrm{~N}=12)\end{array}$ & 0.589 \\
\hline V726A & $20.5(\mathrm{~N}=9)$ & $23.5(\mathrm{~N}=8)$ & 0.684 & $\begin{array}{l}\text { Heterozygote }(\mathrm{N}=16) \\
\text { Homozygote }(\mathrm{N}=1)\end{array}$ & $\begin{array}{l}-(\mathrm{N}=0) \\
-(\mathrm{N}=0)\end{array}$ & $\begin{array}{r}37.5(\mathrm{~N}=6) \\
-(\mathrm{N}=0)\end{array}$ & $\begin{aligned} 62.5(\mathrm{~N} & =10) \\
100.0(\mathrm{~N} & =1)\end{aligned}$ & 0.161 \\
\hline M680I & $25.1(\mathrm{~N}=11)$ & $23.5(\mathrm{~N}=8)$ & 0.972 & $\begin{array}{l}\text { Heterozygote }(\mathrm{N}=16) \\
\text { Homozygote }(\mathrm{N}=3)\end{array}$ & $\begin{array}{l}-(\mathrm{N}=0) \\
-(\mathrm{N}=0)\end{array}$ & $\begin{array}{l}43.8(\mathrm{~N}=7) \\
66.7(\mathrm{~N}=2)\end{array}$ & $\begin{array}{l}56.3(\mathrm{~N}=9) \\
33.3(\mathrm{~N}=1)\end{array}$ & 0.699 \\
\hline E148Q & $11.4(\mathrm{~N}=5)$ & $20.6(\mathrm{~N}=7)$ & 0.218 & $\begin{array}{l}\text { Heterozygote }(\mathrm{N}=12) \\
\text { Homozygote }(\mathrm{N}=0)\end{array}$ & $\begin{array}{r}8.3(\mathrm{~N}=1) \\
-(\mathrm{N}=0)\end{array}$ & $\begin{array}{r}66.7(\mathrm{~N}=8) \\
-(\mathrm{N}=0)\end{array}$ & $\begin{array}{r}25.0(\mathrm{~N}=3) \\
-(\mathrm{N}=0)\end{array}$ & 0.307 \\
\hline M694I & $2.3(\mathrm{~N}=1)$ & $2.9(\mathrm{~N}=1)$ & 0.820 & $\begin{array}{l}\text { Heterozygote }(\mathrm{N}=2) \\
\text { Homozygote }(\mathrm{N}=0)\end{array}$ & $\begin{array}{l}-(\mathrm{N}=0) \\
-(\mathrm{N}=0)\end{array}$ & $\begin{array}{r}100.0(\mathrm{~N}=2) \\
-(\mathrm{N}=0)\end{array}$ & $\begin{array}{l}-(\mathrm{N}=0) \\
-(\mathrm{N}=0)\end{array}$ & 0.610 \\
\hline
\end{tabular}

*Colchicine $0.5 \mathrm{mg}$ tablets were used.

When we compared the treatment doses of colchicine and distributions of MEFV gene mutations, we found statistically significant correlation $(\mathrm{P}>0.05)$. We did not find a statistically significant correlation. Tables 3 and 4 show distributions of genotypes related to $P$ - $g p /$ $M D R 1$ and $C Y P 3 A 4$ polymorphisms by gender. There was no significant difference between females and males in terms of the distribution of $P$-gp/MDRl polymorphisms $(\mathrm{P}>0.05)$. There was also no difference in mean colchicine dose between genotypic variants $(\mathrm{P}>0.05)$.

There were significant differences in the genotypic distributions of $15713 \mathrm{~T}>\mathrm{C}$ and $15615 \mathrm{~T}>\mathrm{C}$ between females and males $(\mathrm{P}=0.03$ and $\mathrm{P}=0.01$, respectively). However, the relationship between colchicine dose and CYP3A4 polymorphism was not significant $(\mathrm{P}>0.05)$. 
Table 3. Distribution of the $P-g p / M D R 1$ genotype with regard to gender and daily colchicine dosing interval.

\begin{tabular}{|c|c|c|c|c|c|}
\hline \multirow[t]{2}{*}{ Polymorphisms } & \multicolumn{2}{|c|}{ Genotypic distribution (\%) } & \multicolumn{3}{|c|}{ Colchicine dose (\%) } \\
\hline & Female $(\mathrm{N}=27)$ & Male $(\mathrm{N}=21)$ & $1 \times 1 *$ & $2 \times 1 *$ & $3 \times 1 *$ \\
\hline \multicolumn{6}{|l|}{ C3435T } \\
\hline $\mathrm{C} / \mathrm{C}$ & $3.7(\mathrm{~N}=1)$ & $-(\mathrm{N}=0)$ & $-(\mathrm{N}=0)$ & $(\mathrm{N}=1)$ & $(\mathrm{N}=0)$ \\
\hline $\mathrm{C} / \mathrm{T}$ & $59.3(\mathrm{~N}=16)$ & $47.6(\mathrm{~N}=10)$ & $-(\mathrm{N}=0)$ & $46.2(\mathrm{~N}=12)$ & $53.8(\mathrm{~N}=14)$ \\
\hline $\mathrm{T} / \mathrm{T}$ & $37.0(\mathrm{~N}=10)$ & $52.4(\mathrm{~N}=11)$ & $9.5(\mathrm{~N}=2)$ & $47.6(\mathrm{~N}=10)$ & $42.9(\mathrm{~N}=9)$ \\
\hline \multicolumn{6}{|l|}{$(-) 1 A>G$} \\
\hline $\mathrm{A} / \mathrm{A}$ & $92.6(\mathrm{~N}=25)$ & $95.2(\mathrm{~N}=20)$ & $-(\mathrm{N}=0)$ & $55.6(\mathrm{~N}=25)$ & $44.4(\mathrm{~N}=20)$ \\
\hline $\mathrm{A} / \mathrm{G}$ & $7.4(\mathrm{~N}=2)$ & $4.8(\mathrm{~N}=1)$ & $33.3(\mathrm{~N}=1)$ & $66.7(\mathrm{~N}=2)$ & $-(\mathrm{N}=0)$ \\
\hline $\mathrm{G} / \mathrm{G}$ & $-(\mathrm{N}=0)$ & $-(\mathrm{N}=0)$ & $-(\mathrm{N}=0)$ & $-(\mathrm{N}=0)$ & $-(N=0)$ \\
\hline \multicolumn{6}{|l|}{$61 \mathrm{~A}>\mathrm{G}$} \\
\hline $\mathrm{A} / \mathrm{A}$ & $92.6(\mathrm{~N}=25)$ & $95.2(\mathrm{~N}=20)$ & $2.2(\mathrm{~N}=1)$ & $55.6(\mathrm{~N}=25)$ & $42.2(\mathrm{~N}=19)$ \\
\hline $\mathrm{A} / \mathrm{G}$ & $7.4(\mathrm{~N}=2)$ & $4.8(\mathrm{~N}=1)$ & $-(\mathrm{N}=0)$ & $-(\mathrm{N}=0)$ & $100.0(\mathrm{~N}=3)$ \\
\hline $\mathrm{G} / \mathrm{G}$ & $-(\mathrm{N}=0)$ & $-(\mathrm{N}=0)$ & $-(\mathrm{N}=0)$ & $-(\mathrm{N}=0)$ & $-(\mathrm{N}=0)$ \\
\hline \multicolumn{6}{|l|}{$1199 \mathrm{G}>\mathrm{A}$} \\
\hline $\mathrm{G} / \mathrm{G}$ & $85.2(\mathrm{~N}=23)$ & $90.5(\mathrm{~N}=19)$ & $2.4(\mathrm{~N}=1)$ & $47.6(\mathrm{~N}=20)$ & $50.0(\mathrm{~N}=21)$ \\
\hline $\mathrm{G} / \mathrm{A}$ & $14.8(\mathrm{~N}=4)$ & $9.5(\mathrm{~N}=2)$ & $-(\mathrm{N}=0)$ & $83.3(\mathrm{~N}=5)$ & $16.7(\mathrm{~N}=1)$ \\
\hline $\mathrm{A} / \mathrm{A}$ & $-(\mathrm{N}=0)$ & $-(\mathrm{N}=0)$ & $-(\mathrm{N}=0)$ & $-(\mathrm{N}=0)$ & $-(\mathrm{N}=0)$ \\
\hline \multicolumn{6}{|l|}{$1236 \mathrm{C}>\mathrm{T}$} \\
\hline $\mathrm{C} / \mathrm{C}$ & $7.4(\mathrm{~N}=2)$ & $33.3(\mathrm{~N}=7)$ & $11.2(\mathrm{~N}=1)$ & $44.4(\mathrm{~N}=4)$ & $44.4(\mathrm{~N}=4)$ \\
\hline $\mathrm{C} / \mathrm{T}$ & $77.8(\mathrm{~N}=21)$ & $38.1(\mathrm{~N}=8)$ & $3.4(\mathrm{~N}=1)$ & $55.2(\mathrm{~N}=16)$ & $41.4(\mathrm{~N}=12)$ \\
\hline $\mathrm{T} / \mathrm{T}$ & $14.8(\mathrm{~N}=4)$ & $28.6(\mathrm{~N}=6)$ & $-(\mathrm{N}=0)$ & $40.0(\mathrm{~N}=4)$ & $60.0(\mathrm{~N}=6)$ \\
\hline \multicolumn{6}{|l|}{$2677 \mathrm{G}>\mathrm{A}$} \\
\hline $\mathrm{G} / \mathrm{G}$ & $100.0(\mathrm{~N}=27)$ & $95.2(\mathrm{~N}=20)$ & $2.1(\mathrm{~N}=1)$ & $51.1(\mathrm{~N}=24)$ & $46.8(\mathrm{~N}=22)$ \\
\hline $\mathrm{G} / \mathrm{A}$ & $-(\mathrm{N}=0)$ & $4.8(\mathrm{~N}=1)$ & $-(\mathrm{N}=0)$ & $100.0(\mathrm{~N}=1)$ & $-(\mathrm{N}=0)$ \\
\hline $\mathrm{A} / \mathrm{A}$ & $-(\mathrm{N}=0)$ & $-(\mathrm{N}=0)$ & $-(\mathrm{N}=0)$ & $-(\mathrm{N}=0)$ & $-(\mathrm{N}=0)$ \\
\hline \multicolumn{6}{|l|}{$2677 \mathrm{G}>\mathrm{T}$} \\
\hline $\mathrm{G} / \mathrm{G}$ & $33.3(\mathrm{~N}=9)$ & $9.5(\mathrm{~N}=2)$ & $-(\mathrm{N}=0)$ & $63.6(\mathrm{~N}=7)$ & $36.4(\mathrm{~N}=4)$ \\
\hline $\mathrm{G} / \mathrm{T}$ & $59.3(\mathrm{~N}=16)$ & $57.2(\mathrm{~N}=12)$ & $3.6(\mathrm{~N}=1)$ & $50.0(\mathrm{~N}=14)$ & $46.4(\mathrm{~N}=13)$ \\
\hline $\mathrm{T} / \mathrm{T}$ & $7.4(\mathrm{~N}=2)$ & $33.3(\mathrm{~N}=7)$ & $-(\mathrm{N}=0)$ & $44.4(\mathrm{~N}=4)$ & $55.6(\mathrm{~N}=5)$ \\
\hline
\end{tabular}

*Colchicine $0.5 \mathrm{mg}$ tablets were used.

Table 4. Distribution of the CYP3A4 genotype with regard to gender and colchicine dose.

\begin{tabular}{|c|c|c|c|c|c|}
\hline \multirow[t]{2}{*}{ Polymorphisms } & \multicolumn{2}{|c|}{ Genotypic distribution (\%) } & \multicolumn{3}{|c|}{ Colchicine dose $(\%)$} \\
\hline & Female $(\mathrm{N}=25)^{\mathrm{a}}$ & Male $(\mathrm{N}=21)$ & $1 \times 1 *$ & $2 \times 1 *$ & $3 \times 1^{*}$ \\
\hline \multicolumn{6}{|l|}{$21896 \mathrm{C}>\mathrm{T}$} \\
\hline $\mathrm{C} / \mathrm{C}$ & $100.0(\mathrm{~N}=25)$ & $100.0(\mathrm{~N}=21)$ & $2.1(\mathrm{~N}=1)$ & $52.2(\mathrm{~N}=24)$ & $45.7(\mathrm{~N}=21)$ \\
\hline $\mathrm{C} / \mathrm{T}$ & $-(\mathrm{N}=0)$ & $-(\mathrm{N}=0)$ & $-(\mathrm{N}=0)$ & $-(\mathrm{N}=0)$ & $-(\mathrm{N}=0)$ \\
\hline $\mathrm{T} / \mathrm{T}$ & $-(\mathrm{N}=0)$ & $-(\mathrm{N}=0)$ & $-(N=0)$ & $-(N=0)$ & $-(N=0)$ \\
\hline \multicolumn{6}{|l|}{$15713 \mathrm{~T}>\mathrm{C}^{\mathrm{b}}$} \\
\hline $\mathrm{T} / \mathrm{T}$ & $92.0(\mathrm{~N}=23)$ & $66.6(\mathrm{~N}=14)$ & $-(\mathrm{N}=0)$ & $89.2(\mathrm{~N}=33)$ & $10.8(\mathrm{~N}=4)$ \\
\hline $\mathrm{C} / \mathrm{T}$ & $8.0(\mathrm{~N}=2)$ & $28.6(\mathrm{~N}=6)$ & $-(\mathrm{N}=0)$ & $12.5(\mathrm{~N}=1)$ & $87.5(\mathrm{~N}=7)$ \\
\hline $\mathrm{C} / \mathrm{C}$ & $-(\mathrm{N}=0)$ & $4.8(\mathrm{~N}=1)$ & $-(\mathrm{N}=0)$ & $-(\mathrm{N}=0)$ & $100.0(\mathrm{~N}=1)$ \\
\hline \multicolumn{6}{|l|}{$-392 A>G$} \\
\hline $\mathrm{A} / \mathrm{A}$ & $92.0(\mathrm{~N}=23)$ & $95.2(\mathrm{~N}=20)$ & $2.4(\mathrm{~N}=1)$ & $48.8(\mathrm{~N}=21)$ & $48.8(\mathrm{~N}=21)$ \\
\hline $\mathrm{A} / \mathrm{G}$ & $8.0(\mathrm{~N}=2)$ & $4.8(\mathrm{~N}=1)$ & $-(\mathrm{N}=0)$ & $66.7(\mathrm{~N}=2)$ & $33.3(\mathrm{~N}=1)$ \\
\hline $\mathrm{G} / \mathrm{G}$ & $-(\mathrm{N}=0)$ & $-(\mathrm{N}=0)$ & $-(N=0)$ & $-(\mathrm{N}=0)$ & $-(\mathrm{N}=0)$ \\
\hline \multicolumn{6}{|l|}{$15615 \mathrm{~T}>\mathrm{C}^{\mathrm{a}, \mathrm{b}}$} \\
\hline $\mathrm{T} / \mathrm{T}$ & $92.0(\mathrm{~N}=23)$ & $62.0(\mathrm{~N}=13)$ & $-(N=0)$ & $61.1(\mathrm{~N}=22)$ & $38.9(\mathrm{~N}=14)$ \\
\hline $\mathrm{T} / \mathrm{C}$ & $-(\mathrm{N}=0)$ & $19.0(\mathrm{~N}=4)$ & $-(N=0)$ & $50.0(\mathrm{~N}=2)$ & $50.0(\mathrm{~N}=2)$ \\
\hline $\mathrm{C} / \mathrm{C}$ & $-(\mathrm{N}=0)$ & $-(\mathrm{N}=0)$ & $-(\mathrm{N}=0)$ & $-(\mathrm{N}=0)$ & $-(\mathrm{N}=0)$ \\
\hline \multicolumn{6}{|l|}{$23171 \mathrm{~T}>\mathrm{C}$} \\
\hline $\mathrm{T} / \mathrm{T}$ & $100.0(\mathrm{~N}=25)$ & $100.0(\mathrm{~N}=21)$ & $2.2(\mathrm{~N}=1)$ & $54.3(\mathrm{~N}=25)$ & $43.5(\mathrm{~N}=20)$ \\
\hline $\mathrm{T} / \mathrm{C}$ & $-(\mathrm{N}=0)$ & $-(\mathrm{N}=0)$ & $-(\mathrm{N}=0)$ & $-(\mathrm{N}=0)$ & $-(\mathrm{N}=0)$ \\
\hline $\mathrm{C} / \mathrm{C}$ & $-(\mathrm{N}=0)$ & $-(\mathrm{N}=0)$ & $-(N=0)$ & $-(\mathrm{N}=0)$ & $-(\mathrm{N}=0)$ \\
\hline
\end{tabular}

*Colchicine $0.5 \mathrm{mg}$ tablets were used; ${ }^{\mathrm{a}}$ some of the patients could not be analyzed due to technical reasons; ${ }^{\mathrm{b}}$ statistically significant $(\mathrm{P}<0.05)$. 


\section{DISCUSSION}

The localization of P-gp/MDR1 and CYP3A indicates that the some of the substrates metabolized by CYP3A may be controlled by P-gp/MDR1. P-gp/MDR1 also mediates the counteracting active transport of drugs back to the lumen after passive absorption into the enterocytes (Cummins et al., 2002). The drug is continuously circulated between the lumen and enterocytes, allowing CYP3A constant access to the drug molecule. This eventually leads to lower drug saturation and non-absorption. Therefore, circulation of the counter transportation of P-gp/MDR1 and metabolism mediated by CYP3A in the intestine reduces oral bioavailability of a drug by controlling the concentration of molecules entering the systemic circulation (Zhou, 2008). Wide inter-individual variations in the expression and activity of CYP3A have been demonstrated in the human liver (Shimada et al., 1994; Westlind et al., 1999). The CYP3A cluster consists of at least 2 members: CYP3A4 and CYP3A5, with polypeptides 4 and 5, respectively, in its protein structure. About $90 \%$ of the inter-individual variability of CYP3A4 activity is caused by genetic factors (Ozdemir et al., 2000; Evans and McLeod 2003). CYP3A4 plays a key role in metabolizing colchicine by demethylating the 3 methoxy groups in the molecule. CYP3A4 activity varies across individuals. The result is decreased colchicine clearance from the body, which affects treatment response (Niel and Shermann, 2006). There is a broad range of overlapping substrate specificities and tissue distribution for CYP3A and P-gp/MDR1 for what are known as CYP/P-gp substrates. P-gp/MDR1 and CYP3A act synergistically as a protective barrier in the bioavailability of orally administered colchicine (Cummins et al., 2002; Niel and Shermann, 2006). To date, more than 40 SNPs in CYP3A4 and more than 50 SNPs in $P$-gp/MDR1 have been identified (Hoffmeyer et al., 2000; Brinkmann and Eichelbaum, 2001; Marzolini et al., 2004; Du et al., 2006). Among them, the most frequently studied SNPs are the G2677T/A transversion (A893S) in exon 21 and the synonymous C3435T transition in exon 26. P-gp/MDR1 SNPs C3435T and G2677T/A affect expression of P-gp and CYP3A4 (Goto et al., 2002; Lamba et al., 2006).

Some FMF patients fail to achieve sufficient response or achieve no response at all despite high doses of colchicine. The threshold between therapeutic and toxic doses of colchicine is narrow and absorption, distribution, and excretion of the drug show significant inter-individual variability (Terkeltaub, 2009). Therefore, we investigated the relationships between polymorphisms in $P$-gp/MDRI and CYP3A4 and treatment dose of colchicine in FMF patients with the aim of establishing the optimal dose of colchicine and reducing adverse effects to a minimum. To serve this purpose, we analyzed 48 patients using colchicine for FMF for presence of CYP3A4 [3435C > T, *1B $(-392 \mathrm{~A}>\mathrm{G}), * 2(15713 \mathrm{~T}>\mathrm{C}), * 3(23171 \mathrm{~T}>\mathrm{C})$, $* 12(21896 \mathrm{C}>\mathrm{T}), * 17(15615 \mathrm{~T}>\mathrm{C})]$ and $P-g p / M D R 1$ [3435C $>\mathrm{T},(-) 1 \mathrm{~A}>\mathrm{G}, 61 \mathrm{~A}>\mathrm{G}, 1199 \mathrm{G}>\mathrm{A}$, $1236 \mathrm{C}>\mathrm{T}, 2677 \mathrm{G}>\mathrm{A}, 2677 \mathrm{G}>\mathrm{T})$ ] polymorphisms. Treatment doses of colchicine among our patients did not differ between genotypic variants of $P$-gp/MDR1 and CYP3A4. Significant gender differences were observed in $15713 \mathrm{~T}>\mathrm{C}$ and $15615 \mathrm{~T}>\mathrm{C}$ polymorphisms of CYP3A4 $(\mathrm{P}$ $=0.03$ and $\mathrm{P}=0.01$, respectively) but not in $P$-gp/MDR1. A study on the Turkish population by Tufan et al. (2007) showed that C3435T of $P$-gp/MDR1 was related to colchicine response in FMF patients and patients with the TT genotype responded better to treatment. However, this contradicts our finding of no significant relationship between clinical response achieved by colchicine treatment dose and CYP3A4 and $P$-gp/MDR1 polymorphisms. On the other hand, it is difficult to fully understand the individual roles of CYP3A4 and $P$-gp/MDR1 in colchicine 
bioavailability and we believe that different epigenetic mechanisms might also be in play.

Hosohata et al. (2009) showed that $P$-gp/MDR1 G2677T/A-C3435T haplotypes significantly influenced intestinal expression in women. Their results suggest that the $P$-gp/ $M D R 1$ haplotype would contribute to the inter-individual variability of intestinal expression of CYP3A4 and CYP3A4-mediated drug interactions. Our results revealed no significant gender difference in $P$-gp/MDR1 polymorphisms. However, $15713 \mathrm{~T}>\mathrm{C}$ and $15615 \mathrm{~T}>\mathrm{C}$ polymorphisms of CYP3A4 were more frequent in males. Therefore, biotransformation of colchicine in males may differ from that in females.

In conclusion, to the best of our knowledge, this is the first study to collectively evaluate polymorphisms of both $P$-gp/MDR1 [3435C $>\mathrm{T},(-) 1 \mathrm{~A}>\mathrm{G}, 61 \mathrm{~A}>\mathrm{G}, 1199 \mathrm{G}>\mathrm{A}$, $1236 \mathrm{C}>\mathrm{T}, 2677 \mathrm{G}>\mathrm{A}, 2677 \mathrm{G}>\mathrm{T})]$ and $C Y P 3 A 4[3435 \mathrm{C}>\mathrm{T}, * 1 \mathrm{~B}(-392 \mathrm{~A}>\mathrm{G}), * 2(15713 \mathrm{~T}>\mathrm{C})$, $* 3(23171 \mathrm{~T}>\mathrm{C}), * 12(21896 \mathrm{C}>\mathrm{T}), * 17(15615 \mathrm{~T}>\mathrm{C})]$ in patients with FMF. The study has addressed the frequency of CYP3A4 polymorphisms in FMF, and the results indicate that CYP3A4 15713T $>\mathrm{C}$ and $15615 \mathrm{~T}>\mathrm{C}$ polymorphisms may be associated with male FMF in the Turkish population. However, $P$-gp/MDR1 and CYP3A4 polymorphisms may not be related to colchicine treatment. These might reflect disparities in different frequencies of $P-g p /$ $M D R 1$ and CYP3A4 polymorphisms in different ethnicities or other genetic factors might be implicated. It would be useful to carry out large population-based epidemiologic studies of $P$-gp/MDRI and CYP3A4 genotypes.

\section{ACKNOWLEDGMENTS}

We thank the patients for participation in this research, and Hatip Aydin for statistical analysis. Research supported by the Abant Izzet Baysal University Fund (Project \#BAP2009.08.03.327).

\section{REFERENCES}

Ambudkar SV, Dey S, Hrycyna CA, Ramachandra M, et al. (1999). Biochemical, cellular, and pharmacological aspects of the multidrug transporter. Anпи. Rev. Pharmacol. Toxicol. 39: 361-398.

Brinkmann U and Eichelbaum M (2001). Polymorphisms in the ABC drug transporter gene MDR1. Pharmacogenomics J. $1: 59-64$.

Cocco G, Chu DC and Pandolfi S (2010). Colchicine in clinical medicine. A guide for internists. Eur. J. Intern. Med. 21: 503-508.

Cummins CL, Jacobsen W and Benet LZ (2002). Unmasking the dynamic interplay between intestinal P-glycoprotein and CYP3A4. J. Pharmacol. Exp. Ther. 300: 1036-1045.

Du J, Xing Q, Xu L, Xu M, et al. (2006). Systematic screening for polymorphisms in the CYP3A4 gene in the Chinese population. Pharmacogenomics 7: 831-841.

Dvorak Z, Modriansky M, Pichard-Garcia L, Balaguer P, et al. (2003). Colchicine down-regulates cytochrome P450 2B6, 2C8, 2C9, and 3A4 in human hepatocytes by affecting their glucocorticoid receptor-mediated regulation. Mol. Pharmacol. 64: 160-169.

Evans WE and McLeod HL (2003). Pharmacogenomics - drug disposition, drug targets, and side effects. N. Engl. J. Med. 348: 538-549.

Ferron GM, Rochdi M, Jusko WJ and Scherrmann JM (1996). Oral absorption characteristics and pharmacokinetics of colchicine in healthy volunteers after single and multiple doses. J. Clin. Pharmacol. 36: 874-883.

Fonnesu C, Cerquaglia C, Giovinale M, Curigliano V, et al. (2009). Familial Mediterranean Fever: a review for clinical management. Joint Bone Spine 76: 227-233.

Goto M, Masuda S, Saito H, Uemoto S, et al. (2002). C3435T polymorphism in the MDR1 gene affects the enterocyte expression level of CYP3A4 rather than Pgp in recipients of living-donor liver transplantation. Pharmacogenetics 
12: 451-457.

Hasler JA (1999). Pharmacogenetics of cytochromes P450. Mol. Aspects Med. 20: 12-137.

Hesselink DA, van Schaik RHN, van der Heiden IP, van der Werf M, et al. (2003). Genetic polymorphisms of the CYP3A4, CYP3A5, and MDR1 genes and pharmacokinetics of the calcineurin inhibitors cyclosporine and tacrolimus. Clin. Pharmacol. Ther. 74: 245-254.

Hoffmeyer S, Burk O, von Richter O, Arnold HP, et al. (2000). Functional polymorphisms of the human multidrugresistance gene: multiple sequence variations and correlation of one allele with P-glycoprotein expression and activity in vivo. Proc. Natl. Acad. Sci. U. S. A. 97: 3473-3478.

Hosohata K, Masuda S, Yonezawa A, Katsura T, et al. (2009). MDR1 haplotypes conferring an increased expression of intestinal CYP3A4 rather than MDR1 in female living-donor liver transplant patients. Pharm. Res. 26: 1590-1595.

Jamroziak K, Mlynarski W, Balcerczak E, Mistygacz M, et al. (2004). Functional C3435T polymorphism of MDR1 gene: an impact on genetic susceptibility and clinical outcome of childhood acute lymphoblastic leukemia. Eur. $J$. Haematol. 72: 314-321.

Kim RB, Leake BF, Choo EF, Dresser GK, et al. (2001). Identification of functionally variant MDR1 alleles among European Americans and African Americans. Clin. Pharmacol. Ther. 70: 189-199.

Kimura Y, Morita SY, Matsuo M and Ueda K (2007). Mechanism of multidrug recognition by MDR1/ABCB1. Cancer Sci. 98: 1303-1310.

Lamba J, Strom S, Venkataramanan R, Thummel KE, et al. (2006). MDRI genotype is associated with hepatic cytochrome P450 3A4 basal and induction phenotype. Clin. Pharmacol. Ther. 79: 325-338.

Lange U, Schumann C and Schmidt KL (2001). Current aspects of colchicine therapy - classical indications and new therapeutic uses. Eur. J. Med. Res. 6: 150-160.

Marzolini C, Paus E, Buclin T and Kim RB (2004). Polymorphisms in human MDR1 (P-glycoprotein): recent advances and clinical relevance. Clin. Pharmacol. Ther. 75: 13-33.

Molad Y (2002). Update on colchicine and its mechanism of action. Curr. Rheumatol. Rep. 4: 252-256.

Nebert DW and Russell DW (2002). Clinical importance of the cytochromes P450. Lancet 360: 1155-1162.

Niel E and Scherrmann JM (2006). Colchicine today. Joint Bone Spine 73: 672-678.

Ozdemir V, Kalow W, Tang BK, Paterson AD, et al. (2000). Evaluation of the genetic component of variability in CYP3A4 activity: a repeated drug administration method. Pharmacogenetics 10: 373-388.

Pras E, Livneh A, Balow JE, Jr., Pras E, et al. (1998). Clinical differences between North African and Iraqi Jews with familial Mediterranean fever. Am. J. Med. Genet. 75: 216-219.

Shimada T, Yamazaki H, Mimura M, Inui Y, et al. (1994). Interindividual variations in human liver cytochrome P-450 enzymes involved in the oxidation of drugs, carcinogens and toxic chemicals: studies with liver microsomes of 30 Japanese and 30 Caucasians. J. Pharmacol. Exp. Ther. 270: 414-423.

Tateishi T, Soucek P, Caraco Y, Guengerich FP, et al. (1997). Colchicine biotransformation by human liver microsomes. Identification of CYP3A4 as the major isoform responsible for colchicine demethylation. Biochem. Pharmacol. 53: 111-116.

Terkeltaub RA (2009). Colchicine update: 2008. Semin. Arthritis Rheum. 38: 411-419.

Tufan A, Babaoglu MO, Akdogan A, Yasar U, et al. (2007). Association of drug transporter gene ABCB1 (MDR1) 3435C to T polymorphism with colchicine response in familial Mediterranean fever. J. Rheumatol. 34: 1540-1544.

Turolo S, Tirelli AS, Ferraresso M, Ghio L, et al. (2010). Frequencies and roles of CYP3A5, CYP3A4 and ABCB1 single nucleotide polymorphisms in Italian teenagers after kidney transplantation. Pharmacol. Rep. 62: 1159-1169.

Vicente J, Sinues B, Fanlo A, Vasquez P, et al. (2008). Polymorphism C3435T of the MDR1 gene in Central Americans and Spaniards. Mol. Biol. Rep. 35: 473-478.

Westlind A, Lofberg L, Tindberg N, Andersson TB, et al. (1999). Interindividual differences in hepatic expression of CYP3A4: relationship to genetic polymorphism in the 5'-upstream regulatory region. Biochem. Biophys. Res. Commun. 259: 201-205.

Zhou SF (2008). Structure, function and regulation of P-glycoprotein and its clinical relevance in drug disposition. Xenobiotica 38: 802-832. 